Acta Universitatis Wratislaviensis No 4001

PRAWO CCCXXXI

Wrocław 2020

https://doi.org/10.19195/0524-4544.331.22

\author{
MAGDALENA TABERNACKA \\ ORCID: 0000-0002-5921-7154 \\ Uniwersytet Wrocławski \\ magdalena.tabernacka@uwr.edu.pl
}

\title{
Kwestia (nie)pomijalności organów administracji publicznej w kontekście obowiązywania przepisów dotyczących nazw ulic
}

\begin{abstract}
Abstrakt: Artykuł dotyczy problemu niepomijalności organów administracji publicznej, zarówno samorządu terytorialnego, jak i administracji rządowej, w kontekście obowiązywania ustawy o zakazie propagowania komunizmu. Istotnymi czynnikami wpływającymi na niepomijalność organów samorządu terytorialnego jest ich ustrojowa pozycja w państwie, co ma związek ze środkami ochrony samodzielności ich działania. Praktyka wykonywania przez organy administracji rządowej kompetencji nadzorczych wynikających z ustawy o zakazie propagowania komunizmu, gdzie można zauważyć swoisty automatyzm działania tych organów, prowadzi do faktycznej pomijalności organów samorządowych, które są organami korzystającymi z gwarantowanej konstytucyjnie samodzielności. Prowadzi to do konfliktów, w których istotną rolę odgrywają następujące czynniki: kwestia oceny historycznego znaczenia pewnych faktów; konieczność zachowania standardu samodzielności jednostek samorządu terytorialnego jako podmiotów zdecentralizowanych; problem tożsamości jednostek samorządu terytorialnego.
\end{abstract}

Słowa kluczowe: administracja publiczna, niepomijalność, totalitaryzm, rozstrzygnięcie nadzorcze, ochrona sądowa samodzielności, decentralizacja, tożsamość.

\section{Aksjologiczne determinanty niepomijalności}

Zgodnie z regulacją art. 7 Konstytucji Rzeczypospolitej Polskiej organy władzy publicznej działają w granicach i na podstawie prawa. Administracja publiczna, a ściślej — jej organy — w demokratycznym państwie prawnym pełnią funkcję wykonawczą, przy czym kwestią kluczową co do ich ustrojowej pozycji jest po- 
siadanie przez nie atrybutu władztwa ${ }^{1}$. Nie realizują żadnych „,własnych” celów ${ }^{2}$ — realizują jedynie, w ramach pełnionej przez siebie funkcji wykonawczej, cele określone prawem, które ustawodawca przydzielił im normami kompetencyjnymi, zgodnie z założeniami wynikającymi z przyjętego w konstytucji porządku ustrojowego. Ponieważ wykonywanie kompetencji wynikającej z przepisów prawa publicznego jest obowiązkiem organów władz publicznych, oznacza to ich niepomijalność przy realizacji zadań, do których zostały powołane normą kompetencyjną.

W polskim modelu ustrojowym realizacja zadań publicznych wykonywana jest $\mathrm{w}$ warunkach działania zarówno zasady centralizacji, jak i decentralizacji. Niepomijalność powinna być cechą funkcjonowania organów działających w warunkach obu tych systemów organizacyjnych. W polskich warunkach ustrojowych zasadnicza część zadań publicznych została powierzona organom samorządu terytorialnego, o czym przesądziła regulacja art. 16 ust. 2 Konstytucji. Zasada decentralizacji jest jedną z naczelnych zasad ustrojowych i dzięki regulacji art. 15 Konstytucji stanowi swoistą, konstytucyjną, gwarancję realizacji zasady subsydiarności w procesie wykonywania zadań publicznych. Przy czym to prawo przesądza o podziale kompetencji, choć równocześnie nie ma ustrojowych możliwości, by organy samorządu były w tym układzie pominięte. Uzasadniona jest więc teza, że przepisy art. 15 i 16 Konstytucji są ustrojową gwarancją niepomijalności organów samorządu terytorialnego w sprawowaniu władzy w Polsce. $Z$ treści art. 15 ustawy zasadniczej wynika, że podział terytorialny dokonany w warunkach decentralizacji władzy publicznej ma zapewnić jednostkom terytorialnym zdolność wykonywania zadań publicznych, co wszakże wymaga doprecyzowania przepisami ustawy, ale jako zasada konstytucyjna nie budzi wątpliwości. Konsekwencją art. 16 Konstytucji jest przyznanie ogółowi mieszkańców, czyli wspólnocie samorządowej ${ }^{3}$, legitymacji do uczestniczenia w wykonywaniu zadań publicznych i wykonywaniu tych zadań, które przysługują samorządowi we własnym imieniu

1 Jak to przedstawia A. Błaś, w państwie prawa administracja publiczna ujmowana jest jako ustrojowa funkcja państwa i samorządu terytorialnego polegająca na wykonywaniu zadań publicznych określonych prawnie. Autor wskazuje władztwo jako kategorię mającą istotne ustrojowo znaczenie w odróżnieniu administracji publicznej od innych podmiotów realizujących zadania publiczne; idem, Administracja publiczna w państwie prawa, [w:] Nauka administracji, red. J. Boć, Wrocław 2013, s. 40.

2 Adam Błaś podkreśla, że administracja publiczna nie ma żadnych własnych praw czy wolności, które by realizowała na własny użytek bądź interpretowanego przez siebie stanu dobrobytu obywateli, spokoju społecznego czy jakiejś innej idei. Administracja nie ma innych funkcji niż wykonywanie zadań publicznych, przypisanych jej prawem powszechnie obowiązującym, stanowionym w sposób niesprzeczny z konstytucją przez ustawodawcę; ibidem, s. 43, 45.

3 Zgodzić się należy z poglądami I. Lipowicz, która analizując poglądy Stanisława Kasznicy, zauważa, że syntetyczne określenie gminy jako „odwiecznej jednostki” w społeczności ludzi związanych bezpośrednim sąsiedztwem zachowuje dziś swoją przydatność i obrazowość. Autorka docenia znaczenie przedstawionej przez autora koncepcji nieakceptacji „ducha centralistycznego — policyjnego", co musi prowadzić do zmiany samodzielnych jednostek w powolne narzędzie w rękach rządu, co w swoich rozważaniach Kasznica łączy z głębokim szacunkiem dla wolności człowieka i jego wspólnot terytorialnych; eadem, Samorzad terytorialny XXI wieku, Warszawa 2019, s. 62, 
i na własną odpowiedzialność. Oznacza to niepomijalność wspólnoty w wykonywaniu zadań publicznych, co będzie miało dalsze konsekwencje przy ocenie konstytucyjności przepisów ingerujących w taki porządek rzeczy.

Efektywne społecznie realizowanie zadań publicznych możliwe jest przy zapewnieniu koherentnego działania organów funkcjonujących w warunkach centralizacji i decentralizacji, przy założeniu takiego podziału kompetencji, który będzie racjonalny i nie będzie przeczył przyjętym założeniom ustrojowym, a przy tym zapewni stabilność realizacji zadań publicznych. Taki stan rzeczy wyklucza wszelką „konkurencję o władzę” między organami administracji samorządowej a organami administracji państwowej czy też rządowej, co powinno dotyczyć zarówno ustawowo przeprowadzonego podziału kompetencji w zakresie realizowania zadań publicznych, jak relacji między organami. W szczególności dotyczy to ustawowych założeń i praktyki realizowania środków nadzoru. Oznacza to oczywiście, że organy administracji samorządowej nie mogą być faktycznie czy też formalnie pomijane w realizacji swoich kompetencji, co dotyczy zarówno działań ustawodawcy, jak i praktyki wykonawczej organów administracji państwowej realizujących kompetencje wobec organów samorządu terytorialnego lub we wspóldziałaniu z organami samorządowymi. Niepomijalność organów samorządowych w demokratycznym państwie prawnym oznacza więc przede wszystkim niemożliwość wyeliminowania ich skutecznego prawnie działania.

Problem (nie)pomijalności administracji publicznej na poziomie samorządu terytorialnego uwidocznił się w związku z realizacją zadań nałożonych na gminy i organy administracji rządowej (wojewodę) przepisami ustawy ${ }^{4} \mathrm{z}$ dnia 1 kwietnia 2016 roku o zakazie propagowania komunizmu lub innego ustroju totalitarnego przez nazwy jednostek organizacyjnych, jednostek pomocniczych gminy, budowli, obiektów i urządzeń użyteczności publicznej oraz pomniki ${ }^{5}$.

\section{Realizacja kompetencji w przedmiocie nazewnictwa ulic - między założeniami ustrojowymi a regulacjami specustawy}

Zgodnie z regulacjami art. 18 ust. 2, pkt 13 ustawy z dnia 8 marca 1990 roku o samorządzie gminnym ${ }^{6}$ podejmowanie uchwał w sprawach nazw ulic i placów będących drogami publicznymi lub nazw dróg wewnętrznych w rozumieniu usta-

63 i cytowany tam S. Kasznica [A. Łużycki], Polskie prawo administracyjne: Pojęcia i instytucje zasadnicze, Warszawa 1938 [1943].

${ }^{4}$ Określanej w literaturze i orzecznictwie jako ustawa dekomunizacyjna lub jako ustawa o zakazie propagowania komunizmu.

5 Dz.U. z 2016 r. poz. 744, z późn. zm. (dalej: ustawa o zakazie propagowania komunizmu).

6 Tekst jedn. Dz.U. z 2020 r. poz. 713, z późn. zm. (dalej: u.s.g.). 
wy z dnia 21 marca 1985 roku o drogach publicznych ${ }^{7}$ należy do wyłącznej właściwości rady gminy.

Ustawa o zakazie propagowania komunizmu wprowadziła szczególny reżim prawny dotyczący zmiany nazw ulic, a także nadawania nowych nazw, który przewiduje znaczne ograniczenie samodzielności gminy w tym przedmiocie, co do zasady gwarantowanej przepisami u.s.g. Wobec tego stanu rzeczy można zaliczyć ustawę o zakazie propagowania komunizmu do kategorii tak zwanych specustaw. Stosowanie przez ustawodawcę tego typu rozwiązań legislacyjnych jest wątpliwe z punktu widzenia niezmiernie istotnej w demokratycznym państwie prawnym stabilności prawa i powiązanego $\mathrm{z}$ tym bezpieczeństwa prawnego obywateli. Jest też niebezpieczne dla praworządności w państwie, gdyż treść zawartych w nich regulacji może de facto „modyfikować” lub jawnie łamać zasady ustrojowe wynikające zkonstytucjilubustaw ustrojowych regulujących funkcjonowanie organów państwa.

W art. 1 ust. 1 ustawy o zakazie propagowania komunizmu wprowadzono generalny zakaz, zgodnie z którym nazwy jednostek organizacyjnych, jednostek pomocniczych gminy, budowli, obiektów i urządzeń użyteczności publicznej, w tym dróg, ulic, mostów i placów, nadawane przez jednostki samorządu terytorialnego nie mogą upamiętniać osób, organizacji, wydarzeń lub dat symbolizujących komunizm lub inny ustrój totalitarny ani w inny sposób takiego ustroju propagować. Ustawodawca w ust. 2 tego artykułu precyzuje ponadto, jakie nazwy uważa się za „propagujące komunizm” — choć należy tu zauważyć, że ustawodawca nie wypowiada się wprost co do zakresu znaczenia pojęcia ,innego ustroju totalitarnego" ani też nie wskazuje w tekście ustawy innych ustrojów totalitarnych, których to określenie by dotyczyło. W efekcie omawiane tu przepisy otwierają bardzo szerokie pole do interpretacji w zakresie tego, jaki ustrój totalitarny jest, a jaki nie. Zaznaczyć należy, że totalitaryzm i jego formalne przejawy ${ }^{8}$ są w nauce gruntownie zbadane, co pozwala na porównanie konkretnych założeń ustro-

7 Dz.U. z 2018 r. poz. 2068, z późn. zm.

8 W ujęciu encyklopedycznym totalitaryzm charakteryzuje się jako system rządów oraz wspierającą go ideologię, w którym ambicje mocarstwowe szły w parze z rozczarowaniem demokracją, jej kryzysem lub niedostatkiem, w tym sensie, że totalitaryzm uważany jest za skrajną i specyficzną postać rządów autorytarnych, nowoczesną odmianę tyranii i despotyzmu zapewniającą rządzącym o wiele skuteczniejszą kontrolę nad społeczeństwem. Cechą totalitaryzmu jest oficjalna, obowiązująca wszystkich ideologia, głosząca radykalne zerwanie z przeszłością, permanentną rewolucję i „,wykuwanie” człowieka nowego typu. Ponadto do jego cech zaliczana jest między innymi centralnie kierowana propaganda, całkowite podporządkowanie zatomizowanego społeczeństwa przez państwo, rządy monopartii, istnienie wyraźnie zdefiniowanego wroga zewnętrznego i wewnętrznego, sterowane poparcie społeczne, monumentalizm w sztuce połączony z wrogością do form uznanych za zdegenerowane, bardzo wybiórczy stosunek do tradycji. Mimo że istnieją znaczne różnice między typami państw totalitarnych, uderzające analogie między nimi pozwalają na wyodrębnienie totalitarnego systemu sprawowania władzy. Totalitaryzm różni się od tradycyjnych rządów autokratycznych przede wszystkim posługiwaniem się nowoczesną techniką i organizacją pracy, bez której niezbędny dla niego stopień kontroli nad społeczeństwem byłby nieosiągalny. Totalitaryzm, [hasło w:] Nowa encyklopedia powszechna PWN, Warszawa 2004, s. 285, 286. W tym kontekście na- 
jowych i prawnych z ustaleniami doktryny. Szerokie pole do interpretacji przepisów ustawy wynika w pierwszym rzędzie z tego, że ustawodawca, wskazując w ust. 2 omawianego tu przepisu jako propagujące komunizm „nazwy odwołujące się do osób, organizacji, wydarzeń lub dat symbolizujących represyjny, autorytarny i niesuwerenny system władzy w Polsce w latach 1944-1989”, posłużył się zwrotem także, co oznacza, że nie jest to katalog zamknięty, a z tego względu regulacja ta nie jest odporna na zmiany zachodzące w obrębie zjawiska, jakim jest tak zwana polityka historyczna.

Ustawodawca przewidział szczególne tryby eliminowania nazw ulic istniejących w dniu wejścia w życie ustawy o zakazie propagowania komunizmu, nieodpowiadających założeniom wynikającym $\mathrm{z}$ art. 1 tej ustawy. Zaznaczyć jednak należy, że w ciągu około trzydziestu lat po upadku komunizmu w Polsce gminy przeprowadzały już zmiany nazw ulic, które w odbiorze społecznym kojarzyły się z minionym ustrojem. Jak zauważa J. Kałużna, zmiany takie rozpoczęły się już w 1989 roku. Autorka powołuje się na badania E. Hałas, która podaje, że w latach 1989-1998 zmienione zostały nazwy 2098 ulic $^{9}$. Jak przypuszcza autorka, większość zmian nazw ulic podyktowana była ich lokalizacją (centrum miasta), osobą patrona (postać oceniana na poziomie wiedzy powszechnej w sposób negatywny) czy lokalnym resentymentem (chęć przywrócenia przedwojennej nazwy ulicy) ${ }^{10}$.

W przepisie art. 6 ust. 1 ustawy o zakazie propagowania komunizmu określono ciążący na gminie generalny obowiązek zmiany nazwy ulicy upamiętniającej osoby, organizacje, wydarzenia lub daty symbolizujące komunizm lub inny ustrój totalitarny, lub propagującej taki ustrój w inny sposób, w terminie dwunastu miesięcy od dnia wejścia w życie ustawy.

Dalsze regulacje ustawy wprowadziły procedurę postępowania w sytuacji, gdyby gminy nie dopełniły obowiązku określonego w art. 6 ust.1. Przepis ust. 2 tego artykułu w takim wypadku przyznał wojewodzie kompetencję do wydania zarządzenia zastępczego w przedmiocie „dostosowania” nazwy do dyspozycji wynikających $\mathrm{z}$ art. 1 ustawy o zakazie propagowania komunizmu w terminie trzech miesięcy od dnia, w którym, zgodnie $\mathrm{z}$ art. 6 ust. 1, powinna była nastąpić zmiana nazwy ulicy. Działanie wojewody w myśl tego przepisu, zgodnie z art. 6 ust. 3, powinno nastąpić po uzyskaniu opinii Instytutu Pamięci Narodowej - Komisji Ścigania Zbrodni przeciwko Narodowi Polskiemu, potwierdzającej niezgodność nazwy ulicy obowiązującej $\mathrm{w}$ dniu wejścia $\mathrm{w}$ życie ustawy z jej art. 1. W art. 6a ust. 1 ustawy o zakazie propagowania komunizmu przewidziano, że w przypadku

leży nadmienić, że ustrojowa pozycja zasady decentralizacji stanowi podstawową zaporę przed ponownym scentralizowaniem państwa i tym samym powinna stanowić barierę przed autorytaryzmem.

9 E. Hałas, Polityka symboliczna i pamięć zbiorowa. Zmiany nazwy ulic po komunizmie, [w:] Zmiana czy stagnacja?, red. M. Marody, Warszawa 2004, s. 132, cyt. za: J. Kałużna, Dekomunizacja przestrzeni publicznej w Polsce - zarys problematyki, „Środkowoeuropejskie Studia Polityczne” 2018, nr 2, s. 157, DOI 10.14746/ssp.2018.2.10

10 J. Kałużna, op. cit., s. 157. 
niewykonania przez gminę zarządzenia zastępczego w terminie trzydziestu dni od dnia jego wejścia w życie wojewoda zapewnia jego wykonanie na jej koszt.

Jako zdecydowanie niekonstytucyjny i przeczący zasadom praworządności należy ocenić przepis art. $6 \mathrm{~b}$ ustawy o zakazie propagowania komunizmu, zgodnie z którym w przypadku nadania nazwy w trybie zarządzenia zastępczego, o którym mowa w art. 3 ust. 1 oraz art. 6 ust. 2 tej ustawy, zmiana tej nazwy przez jednostkę samorządu terytorialnego albo związek, o którym mowa w art. 4, wymaga uprzedniej zgody Instytutu Pamięci Narodowej - Komisji Ścigania Zbrodni przeciwko Narodowi Polskiemu oraz właściwego miejscowo wojewody. Przepis ten de facto jest podstawą dokonywania nadzoru prewencyjnego ${ }^{11}$, przy czym zrównuje w tym zakresie pozycję Instytutu Pamięci Narodowej z pozycją wojewody, będącym na mocy art. 170 Konstytucji organem nadzoru nad działalnością samorządu terytorialnego. Regulacja ta przeczy więc ustrojowej zasadzie decentralizacji, narusza zasadę subsydiarności oraz stoi w sprzeczności z treścią art. 170 Konstytucji.

Zakres specjalnej regulacji prawnej wynikającej z ustawy o zakazie propagowania komunizmu jest na tyle szeroki, że istotnie oddziałuje na samodzielność gmin. Można to też uznać za symptom powszechniejszego zjawiska, o którym pisze M. Handel. Dostrzegł on powiązanie skutków obowiązywania specustaw z kryzysem prawa administracyjnego, w szczególności w kontekście założenia spójności prawa administracyjnego. Autor badał też korelację tych ustaw z problematyką ochrony sytuacji prawnej jednostki. Istotne jest spostrzeżenie autora, który skonstatował, że obecnie stanowienie prawa administracyjnego przesiąknięte jest jego swoistą instrumentalizacją, a podejście do prawa administracyjnego ulega ostatnio znamiennemu odwróceniu. Prawo administracyjne przestaje być bazą dla administrowania, staje się zaś instrumentem działania w sferze administracji publicznej. Pojawiła się praktyka stanowienia prawa na potrzeby chwili; zaczęto traktować je jako formę przekazywania decyzji, a nie jako podstawę wszelkich działań. Prawo administracyjne zaczyna określać pewne doraźne potrzeby, a rzadziej to, jakie cele ogólne uważa się za niezbędne do zrealizowania. Zdaniem autora prawo administracyjne przestaje być podstawą działania administracji, staje się sposobem jej działania. Autor konstatuje, że z pewnością jest to odwrócenie

11 Nadzór prewencyjny w stosunku do podmiotów zdecentralizowanych oznacza w praktyce wyeliminowanie ich samodzielności, zwłaszcza jeżeli nie jest dokonywany wyłącznie z zastosowaniem kryterium legalności. W literaturze i orzecznictwie w wątpliwość podaje się potrzebę prewencji nadzorczej, podkreślając przy tym, że istotą nadzoru jest władcze wkroczenie w działalność jednostki nadzorowanej już po naruszeniu prawa. Sama obawa ewentualnego naruszenia nie uzasadnia jeszcze ingerencji nadzorczej, gdyż nadzór ma służyć wyłącznie przywróceniu stanu zgodnego z prawem. J. Dytko, Proceduralnoprawna determinacja nadzoru wojewody nad działalnościa prawotwórcza organów jednostek samorządu terytorialnego, Wrocław 2013, s. 69 i cyt. tam Z. Rybicki, S. Piątek, Zarys prawa administracyjnego i nauki administracji, Warszawa 1988, s. 263; oraz E. Koniuszewska, Środki prawne ograniczające naduzycia władzy w jednostkach samorzadu terytorialnego w ustrojowym prawie administracyjnym, Warszawa 2009, s. 193; a także wyrok NSA z dnia 8 czerwca 2010 roku (II OSK 642/10). 
pojęć i zasad, i samego sposobu myślenia o prawie. Prawo jest stanowione pod wpływem doraźnych wydarzeń i w celu osiągnięcia spektakularnych efektów ${ }^{12}$. Uzupełnieniem tych refleksji jest opinia P. Szreniawskiego, który pisze, że nie jest prawidłowym stanem istnienie wyjątków od reguł konstytucyjnych, a zatem nie powinno się doprowadzać do obowiązku wynikającego z lex specialis, uchylającego obowiązek wypełniania obowiązków konstytucyjnych ${ }^{13}$, co można odnieść do obowiązku stosowania środków nadzoru, prowadzącego do pomijalności określonych prawnie obowiązków gmin w przedmiocie zadań własnych.

Przepisy ustawy o zakazie propagowania komunizmu ewidentnie mają charakter policyjny. Ich celem ma być ochrona przestrzeni publicznej przed ideami komunizmu i totalitaryzmu. Niemniej jest nad wyraz wątpliwe, czy taki cel ustawy mógł być osiągnięty po przeszło trzydziestu latach funkcjonowania w Polsce rozwiązań ustrojowych demokratycznego państwa prawnego. W tym czasie nastąpiły już stosowne zmiany, a sam ustrój komunistyczny zdecydowanie przeszedł do historii. Czy sam cel i powołanie ustawy nie dyskredytuje władz publicznych i nie osłabia zaufania obywateli do państwa? Czy regulacja taka nie jest w istocie ekscesem mającym wskazać opinii publicznej aktywność określonych organów i, siłą rzeczy, doprowadzić do dyskredytacji innych? Czy ustawa ta sztucznie nie generuje konfliktu na poziomie wartości stanowiącego odwrócenie uwagi od rzeczywistych problemów, przed którymi stoi administracja publiczna? Czy w efekcie nie doprowadziła ona do faktycznej pomijalności zarówno organów zdecentralizowanych, jak i scentralizowanych?

W odpowiedzi na te pytania może pomóc wskazanie roli, jaką w demokratycznym państwie prawnym odgrywać powinna regulacja prawna, określająca obowiązki dla organów administracji publicznej. Zdaniem A. Błasia regulacja prawna zadań publicznych przypisanych państwu i samorządowi terytorialnemu wyklucza możliwość dowolnego kształtowania zakresu tych zadań wedle postulatów formułowanych na gruncie ekonomii, finansów publicznych, nauki zarządzania, socjologii czy nauki o polityce. Zadań publicznych określonych konstytucyjnie nie można swobodnie interpretować, ograniczając lub rozszerzając ich zakres $^{14}$. Co oczywiście dotyczy też ustawodawstwa zwykłego, ale także praktyki wykonywania ustaw.

12 M. Handel, Fragmentaryzacja prawa administracyjnego w wyniku obowiązywania, ,specustaw”, „Internetowy Przegląd Prawniczy” 2018, nr 2, s. 158.

13 P. Szreniawski, Obowiązek w prawie administracyjnym, Lublin 2014, s. 43.

14 A. Błaś, Granice prywatyzacji zadań publicznych w państwie prawa, [w:] Samorząd terytorialny III Rzeczypospolitej Polskiej. 10 lat doświadczeń, red. S. Michałowski, Lublin 2002, s. 306, 307. 


\section{Faktyczne skutki ustawy o zakazie propagowania komunizmu}

Wejście w życie ustawy o zakazie propagowania komunizmu oznaczało obowiązek faktycznej weryfikacji, czy obowiązujące w gminach nazewnictwo ulic nie narusza art. 1 tej ustawy. Instytut Pamięci Narodowej pełnił w tym zakresie swoistą funkcję konsultacyjno-prewencyjną, upubliczniając wykazy ulic, które powinny zostać ,zdekomunizowane" ${ }^{15}$, jak również wykaz ulic błędnie kojarzonych z dyspozycjami ustawy o zakazie propagowania komunizmu ${ }^{16}$.

Analiza orzecznictwa zapadłego w przedmiocie środków nadzoru stosowanych przez wojewodów w związku z obowiązywaniem ustawy o zakazie propagowania komunizmu wskazuje, że wprowadzenie nowych regulacji spowodowało zasadniczo dwa rodzaje ,reakcji” gmin. Można odnotować przypadki, gdy rady gmin podejmowały uchwałę o zmianie nazwy ulicy, pozostawiając literalne dotychczasowe jej brzmienie, ale uzasadniając swoją uchwałę argumentami wskazującymi na nowy kontekst i okoliczności funkcjonowania określonej nazwy ulicy, który nie był sprzeczny z duchem ustawy o zakazie propagowania komunizmu. Ponadto można było zauważyć przypadki, gdy gminy nie podejmowały żadnych działań w przedmiocie zmiany nazwy ulicy, co interpretować można jako wyraz oceny, że nazwa danej ulicy nie stanowi obrazy przepisów o zakazie propagowania komunizmu.

Ocena tego stanu rzeczy musi zostać dokonana w szerszym kontekście organizacyjnym, ekonomicznym i społecznym funkcjonowania nazewnictwa ulic na danym terenie. Przede wszystkim należy zaznaczyć, że nazwy ulic są elementem tożsamości jednostki samorządu terytorialnego. Składnika niezwykle istotnego z punktu widzenia ludzi żyjących na danym terenie. $Z$ socjologicznego punktu widzenia można postawić tezę, że podmioty sfery publicznej, jakimi są między innymi gminy, mają tożsamość ${ }^{17}$ czy też pewien rodzaj zbiorowo odczuwalnej tożsamości, skorelowanej z tożsamością osób zamieszkujących dany obszar lub takich, które wywodzą się z danego obszaru lub ich życie jest z nim jakoś powiązane.

Tożsamość jest jednym z czynników wpływających na wizerunek i mającym znaczenie przy identyfikacji określonego podmiotu. Jej konstruowanie następuje w środowisku społecznym, wobec środowiska społecznego i z uwzględnieniem wszelkich społecznych uwarunkowań mających zastosowanie w tym procesie, za-

15 Zob. https://ipn.gov.pl/pl/upamietnianie/dekomunizacja/zmiany-nazwulic/nazwy-ulic/nazwy-do-zmiany

16 https://ipn.gov.pl/pl/glowna/416,Inne-nazwy-wzbudzajace-kontrowersje.html (dostęp: 25.10.2019). Obecnie w wykazie znajdują się następujące nazwy ulic: 1 Maja, Mieczysława Brauna, Jurija Gagarina, Marcina Kasprzaka, Komuny Paryskiej i Ludwika Waryńskiego.

17 Por. M. Tabernacka, Czynniki ksztattujące tożsamość podmiotów sfery publicznej, [w:] Public Relations w sferze publicznej. Wizerunek i komunikacja, red. M. Tabernacka, A. Szadok-Bratun, Warszawa 2013, s. $105 \mathrm{n}$. 
równo co do samego aktu tworzenia, jak i odbioru jego skutków ${ }^{18}$. Te zjawiska zachodzą także w wypadku nadawania i społecznego odbioru oraz swoistej praktyki co do nieformalnego używania nazw ulic. Nazwa ulicy ma dla społeczności lokalnej wymiar symboliczny i konsolidujący, a przez to dający podstawy dalszej wspólnej egzystencji. Problem ten porusza S. Kapralski, pisząc, że pamięć wchodzi w sojusz zarówno z tożsamością, jak i z przestrzenią, by razem stawić czoła nieodwołalnemu upływowi czasu. Autor przytacza poglądy Giddensa, że tożsamość — z pomocą pamięci - jest budowaniem obszaru stałości, w którym zapamiętana przeszłość łączy się z antycypowaną przyszłością, stając się modalnością istnienia owego ,ja” czy „my”. Autor dochodzi do wniosku, że w ten sposób wytwarza się w nas poczucie bezpieczeństwa ontologicznego, przekonanie o tym, że nasze istnienie jest wystarczająco silne, by w jakiś rozmaicie konkretyzowany kulturowo i z różną siłą przekonujący sposób stawić czoła śmierci ${ }^{19}$. Należy też pamiętać, że każda grupa społeczna dąży do posiadania własnej, specyficznej przestrzeni społecznej, odzwierciedlającej jej systemy wartości, priorytety i aspiracje $\mathrm{e}^{20}$. Przestrzeń taka jest wyraźnie uwarunkowana kulturowo, będąc składnikiem szerszego, nieprzestrzennego systemu wartości, na przykład religijnego, estetycznego — wobec którego zyskuje znaczenie i treść lub też jej percepcję cechują wynikające z tego systemu sentymenty czy emo$c_{j} \mathrm{e}^{21}$. Nie ulega wątpliwości, że funkcjonujące w świadomości społecznej nazwy ulic są istotne do autoidentyfikacji lokalnej społeczności i manifestują postawy ludzi mieszkających w danym miejscu. Po tak długim czasie faktycznego działania samorządu narzucona zmiana nazw ulic to cios w lokalne przyzwyczajenia i tożsamość. Można więc zauważyć, że na gruncie ustawy o zakazie propagowania komunizmu doszło do faktycznego konfliktu wartości między organami działającymi w warunkach centralizacji i decentralizacji. Są to konflikty, które można zakwalifikować jako konflikty na płaszczyźnie politycznej ${ }^{22}$ i konflikty na płaszczyźnie kulturowej ${ }^{23}$.

18 Ibidem, s. 105, 106. W swoich badaniach zaobserwowałam niezwykle znamienne zjawisko trwałości nazw ulic rzeczywiście używanych przez ludność zamieszkującą dane miejsce - w Poznaniu jest to ulica potocznie określana jako Chwałka; we Wrocławiu są to place: 1 Maja i PKWN. Por. ibidem, s. 118.

19 S. Kapralski, Pamięć, przestrzeń, tożsamość. Próba refleksji teoretycznej, [w:] Pamięć, przestrzeń, tożsamość, red. S. Kapralski, Warszawa 2010, s. 10 i cyt. tam A. Giddens, Living in. Post-traditional society, [w:] Reflexive Modernization: Politics, Tradition and Aesthetics in the Modern Social Order, red. U. Beck, S. Giddens, S. Lash, Stanford 1994, s. 80.

20 A. Mejer, Socjologia i przestrzeń miejska, Warszawa 2010, s. 56.

21 Ibidem.

22 Por. M. Tabernacka, Płaszczyzna polityczna konfliktów w administracji publicznej, [w:] Płaszczyzny konfliktów w administracji publicznej, red. M. Tabernacka, R. Raszewska-Skałecka, Warszawa 2010, s. 65-68. Spośród wymienionych tu zjawisk, będących źródłami konfliktów na tej płaszczyźnie, należy wymienić takie czynniki, jak: walka polityczna, która przenosi się w sferę administrowania; zmienność założeń politycznych odnoszących się do działania administracji, w szczególności w zakresie celów działania organów administracji, a także sposobów wartościowania stosowanych w przypadku podejmowania decyzji dyskrecjonalnych.

23 Por. M. Tabernacka, Płaszczyzna kulturowa konfliktów w administracji publicznej, [w:] Płaszczyzny konfliktów..., s. 77-89. Jeżeli chodzi o zjawiska z tego zakresu, generujące konflikty 
Wreszcie należy wskazać, że zmiana nazwy ulicy jest bardzo kosztowna. Koszty ponoszone są przez członków wspólnoty samorządowej pośrednio gdyż z budżetu gminy pokrywana jest wymiana tablic z nazwami ulic, tablic na przystankach komunikacji miejskiej i inne wydatki, które należy uwzględnić w tym zakresie. Znaczne koszty ponoszą także osoby mające miejsce zamieszkania lub prowadzące działalność gospodarczą w obiektach mieszczących się przy ulicy, której nazwa się zmienia.

Można więc zauważyć, że gminy, mając na względzie społeczne i finansowe skutki zmiany nazwy ulicy, dążyły do zaznaczenia swojej niepomijalności, która $\mathrm{w}$ tym aspekcie była realizowana $\mathrm{w}$ interesie społecznym.

\section{4. (Nie)pomijalność działania organu administracji w kontekście rozstrzygnięcia nadzorczego o zmianie nazwy ulicy}

Regulacją art. 6 ust. 2 ustawy o zakazie propagowania komunizmu na wojewodę został nałożony obowiązek zmiany w ciągu trzech miesięcy nazwy ulicy rozstrzygnięciem zastępczym, jeżeli gmina nie wywiązała się z obowiązku zmiany w terminie określonym w ustawie.

Należy rozważyć, czy tak daleko posunięty zakres ingerencji w szczególnej sprawie, jaką jest zmiana nazwy ulicy, nie narusza konstytucyjnej zasady proporcjonalności, zgodnie z którą - co wynika $\mathrm{z}$ art. 31 ust. 3 Konstytucji - ograniczenia w zakresie korzystania z konstytucyjnych wolności i praw mogą nastąpić tylko ustawą i tylko jeżeli są konieczne w demokratycznym państwie dla jego bezpieczeństwa lub porządku publicznego bądź ochrony środowiska, zdrowia i moralności publicznej albo wolności i praw innych osób. Ograniczenia te nie mogą naruszać istoty wolności i praw. Nie wydaje się, by funkcjonujące w przestrzeni publicznej nazwy ulic zagrażały któremukolwiek z tych dóbr, a konieczność respektowania zasady decentralizacji i praw przyznanych jednostkom samorządu terytorialnego przepisami art. 15 i 16 Konstytucji nie budzi wątpliwości.

między organami administracji rządowej a samorządowej oraz w środowiskach lokalnych w związku z obowiązywaniem ustawy o zakazie propagowania komunizmu, do najistotniejszych należą: odmienności warunkowane etnocentryzmem, wystąpienie kolizji wartości oraz działanie stereotypów. Konflikt na płaszczyźnie kulturowej przyjmuje często postać konfliktu wartości, których spór dotyczy, realizacji albo uznania wartości istotnych z uwagi na tradycję czy system moralny przyjęty w danej społeczności. W tego typu konfliktach wartości pełnią funkcję „,sztandaru”, pod którym można podążać w odmiennym niż reszta społeczeństwa kierunku lub używać go jako czynnika legitymizującego dyskredytację pewnych grup społecznych. Ibidem, s. 80-81. 
Na gruncie analizowanej ustawy ukształtowało się orzecznictwo akceptujące wolę gminy do zachowania dotychczasowego, literalnego brzmienia nazwy ulicy $^{24}$. Jako przykład można podać wyrok NSA z 20 marca 2019 roku ${ }^{25}$, który dotyczył zmiany nazwy ulicy w Ostrzeszowie, dokonanej rozstrzygnięciem nadzorczym wojewody wielkopolskiego. W tym przypadku Rada Miejska uchyliła wcześniejszą uchwałę Prezydium Miejskiej Rady Narodowej z 1951 roku w sprawie nadania ulicy nazwy „21 Stycznia” i równocześnie nadała nazwę w takim samym literalnym brzmieniu, co uzasadniono tym, że data upamiętnia ocalenie od śmierci przez rozstrzelanie około osiemdziesięciu mieszkańców Ziemi Ostrzeszowskiej, którzy 21 stycznia 1945 roku mieli zostać zgładzeni przez hitlerowców jako zakładnicy. Orzekając w przedmiocie skargi kasacyjnej na wyrok sądu pierwszej instancji, utrzymujący w mocy uchwałę Rady Miejskiej sąd stwierdził, że ze względu na to, że gmina wywiązała się z obowiązku zmiany nazwy, skorzystanie $\mathrm{z}$ trybu wydawania zarządzenia zastępczego, na podstawie art. 6 ust. 2 ustawy dekomunizacyjnej, było działaniem $\mathrm{z}$ istotnym naruszeniem prawa. Zdaniem sądu, z którym należy się zgodzić, przepis ten przyznaje kompetencję organowi nadzoru do wydania zarządzenia zastępczego tylko wtedy, gdy rada gminy nie wykona obowiązku dokonania zmiany nazwy ulicy.

$\mathrm{Z}$ formalnego punktu widzenia podobny jest przypadek ulicy 14 lutego w Pile. Sprawa ta była przedmiotem orzekania Wojewódzkiego Sądu Administracyjnego w Poznaniu ${ }^{26}$, który stanął na stanowisku, że nie ma znaczenia dla ustalenia właściwego trybu weryfikacji przez wojewodę nazw ulic nadanych już po wejściu w życie ustawy dekomunizacyjnej fakt, że nazwa nadana uchwałą podjętą już po wejściu $\mathrm{w}$ życie tej ustawy jest tożsama z nazwą obowiązującą przed dniem wejścia $\mathrm{w}$ życie ustawy. Jak sąd ustalił, uchwała ta, mająca walor aktu prawa miejscowego, została ogłoszona w sposób prawem przewidziany w odpowiednim publikatorze urzędowym - a to oznacza, że dana ulica nosi przypisaną jej nazwę wyłącznie na podstawie tego aktu prawa miejscowego, a nie aktów wcześniejszych, obowiązujących $\mathrm{w}$ dniu wejścia w życie ustawy dekomunizacyjnej. Zgodnie ze stanowiskiem sądu w następstwie tego zastosowanie w stosunku do nazw nadanych uchwałami jednostek samorządu terytorialnego podjętymi już po wejściu w życie ustawy trybu art. 6 ust. 2 i wydanie na tej podstawie prawnej zarządzenia zastępczego będzie musiało być uznane za naruszenie tegoż przepisu poprzez jego niewłaściwe zastosowanie. Następnie w sprawie tej orzekał NSA ${ }^{27}$, który podzielił stanowisko sądu pierwszej instancji. Sąd oparł swoje przekonanie między innymi na tym, że Rada Miasta Piły w uzasadnieniu powziętej przez sie-

24 Na przykład wyrok NSA z dnia 20 marca 2019 roku, II OSK 3228/18; wyrok NSA z dnia 20 marca 2019 roku, II OSK 3413/18; wyrok WSA w Poznaniu z dnia 12 września 2018 roku, II SA/Po 553/18.

25 II OSK 3228/18.

26 Wyrok z dnia 12 września 2018 roku, II SA/Po 553/18.

27 Wyrok NSA z dnia 20 marca 2019 roku, II OSK 3413/18. 
bie uchwały wykazała, że nazwa dotyczy uhonorowania dnia świętego Walentego jako patrona osób zakochanych, a także, że obchody świeckie tego dnia obejmują również uroczystości religijne poświęcone świętemu Walentemu, wobec czego uznać należy, że gmina wywiązała się z obowiązku nałożonego ustawą, co w konsekwencji wyłącza możliwość zastosowania przez wojewodę art. 6 ust. 1 ustawy o zakazie propagowania komunizmu.

Ważnym aspektem niepomijalności gminy w realizowaniu kompetencji w przedmiocie nazewnictwa ulic w kontekście obowiązywania ustawy o zakazie propagowania komunizmu jest obowiązek rzetelnego działania organu nadzoru, co znalazło także swój wyraz w orzecznictwie, szczególnie w kontekście oceny dokonywanej z punktu widzenia art. 1 ustawy o zakazie propagowania komunizmu - nazw nowych ulic czy obiektów, co do których ta ustawa znajduje zastosowanie, czy też gdy gminy nie powzięły decyzji o zmianie nazwy ulicy, uznając, że nazwa ta nie przyczynia się do propagowania komunizmu lub innego ustroju totalitarnego czy też nie symbolizuje takich ustrojów. Naczelny Sąd Administracyjny wyraził $\mathrm{w}$ tym przedmiocie opinię znajdującą uniwersalne zastosowanie, stwierdzając w wyroku z dnia 26 czerwca 2018 roku $^{28}$, że zarządzenie zastępcze, wydane w warunkach ustawy o zakazie propagowania komunizmu, jak każdy środek nadzoru tego rodzaju, powinien czynić zadość normom gwarantującym rzetelne prowadzenie postępowania nadzorczego w sposób rzeczywiście umożliwiający ocenę zgodności z prawem nadzorowanej działalności organu samorządu gminnego, stosownie do art. 85 u.s.g. W opinii sądu wojewoda powinien poczynić ustalenia faktyczne, pozwalające mu na subsumpcję materialnych przesłanek wynikających z art. 6 ust. 1 i 2 ustawy w oparciu o możliwie najpełniejszy i obiektywnie zbadany materiał dowodowy.

\section{Samopomijalność organu nadzoru w kontekście automatyzmu akceptowania opinii IPN}

Zgodnie z art. 6 ust. 3 ustawy o zakazie propagowania komunizmu wydanie przez wojewodę zarządzenia zastępczego w przedmiocie dostosowania nazwy ulicy do wymogów w niej określonych wymaga opinii Instytutu Pamięci Narodowej - Komisji Ścigania Zbrodni przeciwko Narodowi Polskiemu potwierdzającej niezgodność nazwy obowiązującej w dniu wejścia w życie tej ustawy. Stan orzecznictwa w tym zakresie doprowadził do ujawnienia praktyki bezrefleksyjnego traktowania owych opinii jako „podkładki” warunkującej w sposób ścisły wydanie rozstrzygnięcia nadzorczego. Wydawane w takich przypadkach rozstrzy-

28 II OSK 1585/19. 
gnięcia nadzorcze nie zawierały własnej oceny przeprowadzanej przez wojewodę, lecz jedynie powołanie na opinię wystawioną przez IPN.

Pamiętać należy, że to organ nadzoru jest odpowiedzialny za treść rozstrzygnięcia nadzorczego $i$ to na nim ciąży obowiązek konfrontacji stanu faktycznego z zasadnością podjęcia działania przez organ nadzorowany, skonfrontowania go z obowiązującym stanem prawnym i rozstrzygnięcia wszelkich wątpliwości, jakie rysowałyby się na tle analizy stanu faktycznego i prawnego w danej sprawie.

Naczelny Sąd Administracyjny wypowiadał się wielokrotnie wprost na temat charakteru prawnego opinii wydawanej w przedmiocie zmiany nazwy ulicy w trybie przepisów ustawy o zakazie propagowania komunizmu. Pogłębiona analiza znaczenia prawnego opinii wydawanej w trybie art. 6 ust. 3 ustawy o zakazie propagowania komunizmu została przeprowadzona w wyroku z dnia 7 grudnia 2018 roku przez Naczelny Sąd Administracyjny ${ }^{29}$.

Zdaniem sądu opinia IPN wydana na podstawie art. 6 ust. 3 jest niewiążącym wojewodę stanowiskiem tego podmiotu, co wynika z tego, że żaden przepis ustawy dekomunizacyjnej nie stwierdza, że taka opinia wiąże organ, który o nią się zwrócił.

Ponadto sąd, uzasadniając swoje stanowisko, odniósł się do ustrojowych założeń dokonywania nadzoru nad jednostkami samorządu terytorialnego i w tym kontekście ocenił pozycję ustrojową Instytutu Pamięci Narodowej. Sąd odniósł się do regulacji art. 171 Konstytucji określającego legalność jako kryterium nadzoru sprawowanego nad działalnością samorządu terytorialnego oraz przewidującego w ust. 2 zamknięty katalog organów kompetentnych w przedmiocie sprawowania nadzoru nad samorządem terytorialnym, którymi są Prezes Rady Ministrów i wojewodowie, a w zakresie spraw finansowych — regionalne izby obrachunkowe. Zdaniem sądu przyjęcie w drodze wykładni, że opinia IPN jest wiążąca dla wojewody, prowadziłoby do tego, że to IPN byłby w istocie organem nadzoru nad działalnością samorządu, gdyż wojewoda, związany opinią tego podmiotu, nie miałby żadnych istotnych kompetencji w zakresie nadzoru. NSA powołał się na wcześniej wyrażoną w tej kwestii ocenę charakteru opinii IPN, przedstawioną już w orzecznictwie NSA, przede wszystkim w wyroku z 17 kwietnia 2018 roku, sygn. akt II OSK 658/18.

Sąd powołał się też na wielokrotnie później potwierdzone stanowisko Sądu Najwyższego o orzecznictwie sądów administracyjnych w przedmiocie charakteru opinii IPN, wydanej w trybie przepisów ustawy o zakazie propagowania komunizmu, wyrażone w uchwale podjętej przez ten sąd dnia 6 lutego 1996 roku $^{30}$, z której, zdaniem NSA, wynika, jak w języku prawniczym rozumiane jest słowo „opinia” w kontekście współdziałania różnych podmiotów. Zdaniem SN wydanie opinii jest współdziałaniem organów administracji o najsłabszym stopniu związania. Sąd Najwyższy w powołanej uchwale uznał, że podmioty nie są prawnie

29 II OSK 2426/18.

30 III AZP 26/95. 
związane stanowiskiem podmiotów współdziałających, a celem tych form współdziałania jest poszerzenie wiedzy danego podmiotu o problemie, wzbogacenie obrazu sprawy dzięki innemu spojrzeniu podmiotu opiniującego, konsultującego czy doradczego, oraz że można „,co najwyżej wymagać, aby podmiot właściwy do załatwienia sprawy uzasadnił swoje stanowisko odbiegające od opinii”.

Zdaniem Naczelnego Sądu Administracyjnego, wyrażonego w przytaczanym tu orzeczeniu, konsekwencją ustawowych przesłanek wydania przez wojewodę rozstrzygnięcia nadzorczego, na podstawie art. 6 ust. 1 i 2 ustawy o zakazie propagowania komunizmu, to, że IPN w swojej opinii powinien zająć stanowisko co do podstawowej przesłanki wydania zarządzenia zastępczego, czyli „tego, czy nazwa jednostki organizacyjnej, jednostki pomocniczej gminy, budowli, obiektu lub urządzenia użyteczności publicznej upamiętnia osobę, organizację, wydarzenie lub datę symbolizującą komunizm lub inny ustrój totalitarny albo propaguje komunizm przez to, że odwołuje się do osoby, organizacji, wydarzenia lub daty symbolizującej represyjny, autorytarny i niesuwerenny system władzy w Polsce w latach 1944-1989. Z przedstawionego ukształtowania przez ustawodawcę opinii, w szczególności z tego, że powinna się ona odnosić do podstawowej przesłanki wydania zarządzenia zastępczego oraz z tego, że ustawodawca powierzył jej wydanie podmiotowi wyspecjalizowanemu m.in. w zakresie prowadzenia badań naukowych nad porozbiorową i najnowszą historią Polski (art. 53 pkt 2 ustawy o IPN) wynika, że pełni ona nie tyle funkcję dowodu z opinii biegłego, co stanowiska wyspecjalizowanego podmiotu w przedmiocie rozstrzygnięcia podejmowanego przez organ nadzoru". Sąd stanął na stanowczym stanowisku, że z uwagi na to, iż opinia ta nie wiąże wojewody, „organ nadzoru jest zobowiązany przy podejmowaniu rozstrzygnięcia odnieść się do tej opinii przez wyjaśnienie, czy podziela jej wnioski. Inaczej mówiąc organ nadzoru jest zobowiązany opinię IPN ocenić pod kątem tego, czy przekonująco wykazano w niej, że poddawana analizie nazwa jest zgodna $\mathrm{z}$ art. 1 ustawy o zakazie propagowania komunizmu. W związku z tym opinia musi być uzasadniona. Brak uzasadnienia wykluczałby lub co najmniej istotnie utrudniałby odniesienie się do wniosków opinii”.

Należy się zgodzić z pozostałymi tezami cytowanego orzeczenia NSA, które trzeba odnieść do autoniepomijalności wojewody, w tym przypadku — przy dokonywaniu działań nadzorczych na gruncie ustawy o zakazie propagowania komunizmu. Na poparcie w szczególności zasługują następujące tezy przytaczanego orzeczenia: rozstrzygnięcie nadzorcze nie może opierać się jedynie na konkluzji wynikającej z treści opinii niepopartej innymi dowodami, dokumentami czy ocenami ${ }^{31}$. Ponadto słuszna jest teza, że wojewoda ma obowiązek wyczerpującego zebrania, rozpatrzenia i ocenienia materiału dowodowego w odniesieniu do rozstrzygnięcia nadzorczego. Oprócz tego sąd ma rację, konkludując, że wojewoda nie może ograniczać się do uzyskania jedynie wymaganej wprost przepisem art. 6

31 NSA odwołał się tu do wcześniejszych wyroków: NSA z dnia 17 kwietnia 2018 roku, sygn. akt II OSK 658/18; NSA z dnia 6 czerwca 2018 roku, sygn. akt II OSK 786/18. 
ust. 3 opinii Instytutu Pamięci Narodowej; opinia ta nie jest dowodem jedynym i przesądzającym; w żadnym zaś razie nie stanowi aktu rozstrzygającego sprawę zmiany nazwy (dekomunizacji) ulicy i dlatego wojewoda powinien traktować ją tylko jako jeden z dowodów w sprawie. Sąd słusznie zauważył również, że organ nadzoru nie działa jako organ współkompetentny, gdyż opinia IPN nie jest wydawana w trybie współdziałania organów, o którym mowa w przepisach art. 106 $\S 1-5$ k.p.a. Natomiast do obowiązków formalnych wojewody odnosi się konkluzja, że wprawdzie organ nadzorczy w tym typie spraw nie „może wkraczać w merytoryczną zasadność opinii w zakresie, w jakim opinia przedstawia oceny oparte o wiadomości specjalne. Bada natomiast kompletność opinii, jej poprawność metodologiczną i to, czy ocena końcowa jest logicznym następstwem zebranego materiału faktograficznego".

Rzetelne wykonywanie zadań publicznych, zwłaszcza za pomocą środków władczych, nie może przebiegać w warunkach ,automatyzmu myślenia” czy też „wybierania drogi na skróty” w ocenie materiału dowodowego i uwzględnianiu przesłanek działania przez organ. Stosowanie jakiegokolwiek schematu poznawczego, pozwalającego na klasyfikację nazewnictwa ulic bez przeprowadzenia dogłębnej analizy uwarunkowań lokalnych zachodzących w danej społeczności w konkretnym przypadku albo też założenie z góry, że organ gminy postępuje ,źle i złośliwie", pozostawiając literalne brzmienie poprzedniej nazwy, za to uzasadniając jej nadanie przesłankami akceptowalnymi w kontekście ustawy o zakazie propagowania komunizmu, można uznać za nadużycie prawa.

W kontekście stosowania „autopomijalnego” automatyzmu oceny sytuacji przez organ nadzoru warto poddać pod rozwagę, czy takie stosowanie kompetencji nie odpowiada koncepcji nadużycia prawa, czego składową jest nadużycie procedury ${ }^{32}$, o którym pisze J. Parchomiuk. Autor zauważa, że koncepcja nadużycia procedury może być przydatnym instrumentem ograniczenia ingerencji administracji ze względu na pojawiające się w ostatnich latach zjawisko mnożenia specjalnych regulacji prawnych ${ }^{33}$ i w tym kontekście należy przytoczyć stanowisko autora, zgodnie z którym koncepcja nadużycia władzy (prawa przez władzę, przyp. - M.T.) zapobiega wykładni rozszerzającej poprzez wykorzystywanie kompetencji w sposób i do celów innych niż przewidziane przez ustawodawcę ${ }^{34}$.

32 Jak pisze autor, koncepcja ta wywodzi się z doktryny i judykatury francuskiej i zgodnie $\mathrm{z}$ tym ujęciem nadużyciem jest zastosowanie procedury w celu odmiennym od tego, do którego realizacji została przez ustawodawcę przewidziana. Chodzi o sytuację, w której organ wybiera jedną z procedur, potencjalnie mających zastosowanie w miejsce innej, pomimo że nie zostały spełnione przewidziane prawem przesłanki, niemniej zastosowanie wybranej procedury daje organowi określone korzyści. J. Parchomiuk, Wpływ koncepcji nadużycia prawa na administracyjnoprawny status jednostki, [w:] Jednostka wobec działań administracji publicznej, red. E. Ura, E. Feret, S. Pieprzny, Rzeszów 2016, s. 198 i cyt. tam R. Chapus, Droit administratif général, t. 1, Paris 2001, s. 1048-1054; J.M. de Forges, Droit administratif, Paris 1992, s. 278; Y. Gaudemet, Traité de droit administratif, Paris 2001, s. 495-498; J. Waline, Droit administratif, Paris 2008, s. 606-608.

33 J. Parchomiuk, op. cit., s. 199.

34 Ibidem, s. 205. 


\section{Niepomijalność organów samorządu terytorialnego w kontekście prawa do ochrony sądowej samodzielności ich działania}

Niepomijalność jednostek samorządu terytorialnego uwidacznia się wyraźnie w konstytucyjnie zagwarantowanym prawie do ochrony sądowej ich samodzielności. Sądowa ochrona samodzielności jednostek samorządu terytorialnego gwarantowana jest art. 165 ust. 2, zgodnie z którym samodzielność jednostek samorządu terytorialnego podlega ochronie sądowej. Również regulacja art. $11 \mathrm{Eu}-$ ropejskiej karty samorządu lokalnego ${ }^{35}$ przesądza o tym, że społeczności lokalne mają prawo do odwołania na drodze sądowej, w celu zapewnienia swobodnego wykonywania uprawnień oraz poszanowania zasad samorządności lokalnej, przewidzianych w Konstytucji lub w prawie wewnętrznym.

Regulacja art. 6c ustawy o zakazie propagowania komunizmu wprowadza szczególne warunki „,możliwości” wniesienia skargi do sądu. Przepis ten przewiduje, że skarga do sądu administracyjnego na zarządzenie zastępcze, o którym mowa w art. 3 ust. 1 oraz art. 6 ust. 2, przysługuje jednostce samorządu terytorialnego, jedynie gdy brakuje możliwości wykonania obowiązku, o którym mowa w art. 3 ust. 1 oraz art. 6 ust. 1, co wynikało z przyczyn niezależnych od tej jednostki albo związku.

Przepis art. 6c ustawy o zakazie propagowania komunizmu uznać należy za niekonstytucyjny. Nadawanie nazw ulic przez gminę jest przyznanym ustawą zadaniem własnym gminy odpowiadającym w pełni założeniom zasady subsydiarności i decentralizacji, które gwarantują gminom wykonywanie we własnym imieniu i na własną odpowiedzialność zadań o charakterze lokalnym, istotnych dla danej społeczności. Komentowany tu przepis de facto wyłącza możliwość złożenia skargi na zarządzenie zastępcze, o którym mowa w art. 3 ust. 1 oraz art. 6 ust. 2 ustawy, uzależniając możliwość złożenia takiej skargi od wystąpienia niemożliwości wykonania obowiązku, o którym mowa w art. 3 ust. 1 oraz art. 6 ust. 1, co wynikałoby z przyczyn niezależnych od tej jednostki. Ustawa nie podaje przy tym katalogu „przyczyn niezależnych”.

Odnosząc się do skutków prawnych tej regulacji, Wojewódzki Sąd Administracyjny w Poznaniu (II SA/Po 843/18) stwierdził, że takie brzmienie przepisu art. 6c sprowadza się, zgodnie z jego literalnym brzmieniem, do pozbawienia jednostki samorządu terytorialnego gwarantowanej jej art. 165 ust. 2 Konstytucji RP ochrony sądowej w tych przypadkach, których nie ujęto we wskazanej regulacji. W szczególności ochrona sądowa byłaby wykluczona w każdym przypadku uznania przez organ samorządu terytorialnego, że w wyznaczonym ustawą dwunastomiesięcznym terminie nie zachodzą przesłanki do zastosowania przepisów ustawy i niedokonania zmiany nazwy ulicy. Prowadziłoby to do rażącego naruszenia

35 Dz.U. z 1994 r. Nr 124, poz. 607 z późn. zm. 
art. 165 ust. 2 Konstytucji RP przez wyłączenie spod kontroli sądowej działania organu nadzoru, opartego na jego uznaniu w zakresie oceny, co jest symbolem komunizmu. Sąd wyraził opinię, że wobec tego treści art. 6c ustawy o zakazie propagowania komunizmu nie da się pogodzić z art. 165 ust. 2 Konstytucji oraz art. 11 Europejskiej karty samorządu lokalnego, co w sprawie, którą rozpatrywał sąd, było podstawą do ich bezpośredniego stosowania. Pogląd ten zaaprobował NSA w wyroku z dnia 26 czerwca 2019 roku $^{36}$, którego zdaniem prawo jednostki samorządu terytorialnego do ochrony sądowej w razie wydania zarządzenia zastępczego, które — jej zdaniem — nadmiernie ingeruje w jej samodzielność, nie może być rozważane tylko na drodze literalnej wykładni ustawy, dokonanej w oderwaniu od tej innej regulacji, zwłaszcza konstytucyjnej. Jak stwierdził sąd, wykładnia ta musi być osadzona $w$ ramach ustrojowych, szczególnie zakreślonych przez przepisy znajdujące się wyżej w hierarchii aktów prawnych, wyznaczających pozycję tych jednostek, instrumenty nadzoru nad nimi oraz przysługujące im środki prawne zabezpieczające tę pozycję w razie nadużywania takich instrumentów. Dlatego art. 6c ustawy nie może być rozumiany jako ograniczenie gwarantowanej w art. 165 ust. 2 Konstytucji ochrony sądowej samodzielności gminy ${ }^{37}$. Zdaniem sądu niepodobna podzielić argumentu, jakoby art. 6c ustawy mógł wyłączać zasadę bezpośredniego stosowania Konstytucji, ustanowioną w jej art. 8, gdyż trudno przyjąć, by rozwiązanie ustawowe mogło pozbawić sąd pierwszej instancji kompetencji, jakie przysługują mu w rozpatrywanej materii, i to w sytuacji, gdy stwierdził on, że jest ono nie do pogodzenia z Konstytucją i nie pozwala na realizację wynikających z niej praw. Komentując te dwa orzeczenia, należy stwierdzić, że równocześnie można powiedzieć o niepomijalności organu administracji oraz działalności sądu w ocenie realizacji kompetencji przez organ administracji.

W przedmiocie obowiązywania ustawy o zakazie propagowania komunizmu zdolność sądowa gmin została generalnie potwierdzona w utrwalonym orzecznictwie. Na przykład Naczelny Sąd Administracyjny w wyroku z dnia 20 marca 2019 roku $^{38}$ potwierdził, że art. 165 ust. 2 Konstytucji RP gwarantuje samorządowi samodzielność, czyniąc ją jedną z podstawowych zasad ustrojowych. Gwarancją przestrzegania tej zasady, jak również jej funkcjonowania w obrocie prawnym, jest prawo do sądu, przysługujące każdej jednostce samorządu, w przypadku gdy inny podmiot lub organ administracyjny podejmuje jakiekolwiek działania władcze, skierowane wobec danej jednostki samorządu terytorialnego. Skoro zgodnie z art. 16 ust. 2 Konstytucji RP to samorząd terytorialny wykonuje istotną część zadań publicznych we własnym imieniu i na własną odpowiedzialność, to każdorazowe wkroczenie $\mathrm{w}$ wykonywanie takiego zadania przez inny podmiot musi pociągać za sobą prawo samorządu do sądowej ochrony przed takim działaniem.

36 II OSK 1585/19.

37 Sąd powołał się tu na orzeczenie: postanowienie Naczelnego Sądu Administracyjnego z dnia 15 listopada 2018 roku, sygn. akt II OSK 3045/18.

${ }^{38}$ II OSK 3228/18 - wyrok NSA. 
Przyjęcie odmiennego założenia skutkowałoby wprowadzeniem centralizacji administracji publicznej w miejsce decentralizacji wraz z uprawnieniem do substytucji, czyli przeniesienia danej sprawy do wykonywania przez inny podmiot.

Można zauważyć, że NSA w tym wyroku pośrednio wypowiedział się na temat (nie)pomijalności organów samorządowych w sprawowaniu władzy. $Z$ orzeczenia tego wynika, że pozbawienie samorządu prawa do skarżenia aktu dotyczącego wykonywania zadania, które — co do zasady — wykonuje organ samorządu, a w danym wypadku (na przykład w trybie nadzoru) było wykonane przez organ administracji rządowej, stanowi już daleko idącą ingerencję w samodzielność samorządu, to dodatkowo przesądzałoby o negowaniu samorządu terytorialnego jako odrębnego, wykonującego we własnym imieniu i na własną odpowiedzialność zadania publiczne. Sąd doszedł więc do wniosku, że tym samym, w stosunku do art. 6c ustawy o zakazie propagowania komunizmu, nie można dokonywać wykładni rozszerzającej i twierdzić, że każde zarządzenie zastępcze wydane na podstawie ustawy dekomunizacyjnej podlega wyłączeniu z prawa do jego zaskarżenia przez jednostkę samorządu do sądu administracyjnego. Stanowiłoby to nie tylko naruszenie konstytucyjnej zasady samodzielności samorządu i prawa do jej sądowej ochrony, ale także musiałoby prowadzić do uznania za legalne działania organu nadzoru, mimo że taki organ wydawałby zarządzenia zastępcze z naruszeniem ustawy, a wobec braku prawa do ich zaskarżenia - takie zarządzenia stanowiłyby część obowiązującego porządku prawnego. Taka sytuacja jest niedopuszczalna w demokratycznym państwie prawnym, w którym każde działanie organów władzy publicznej musi być oparte na przepisach prawa i być podejmowane w granicach prawa.

Tezy te uzupełnia stanowisko Wojewódzkiego Sądu Administracyjnego w Poznaniu, który w wyroku z dnia 17 stycznia 2019 roku $^{39}$ stwierdził, że przepis art. 165 ust. 2 Konstytucji RP nie przewiduje wyjątków od kreowanej w nim zasady sądowej ochrony samodzielności jednostek samorządu terytorialnego. Nie odsyła także do ustaw szczególnych, które mogłyby ograniczać tę zasadę. Należy zatem w pełni podzielić pogląd Sądu Najwyższego, wyrażony w postanowieniu z dnia 3 września 1998 roku, sygn. akt III RN 49/98 (System Informacji Prawnej Lex poz. 35586), zgodnie z którym art. 165 ust. 2 Konstytucji RP podlega bezpośredniemu stosowaniu przez sądy na podstawie art. 8 ust. 2 Konstytucji i wynika z niego obowiązek stosowania przez sądy takiej wykładni przepisów prawa, by zapewnić jednostkom samorządu terytorialnego prawo do sądu.

39 II SA/Po 843/18. 


\section{Konkluzje}

Kategoria niepomijalności administracji w aspekcie stosowania przepisów ustawy o zakazie propagowania komunizmu odnosi się do organów samorządu terytorialnego w kontekście jego ustrojowej roli, zadań wyznaczonych prawem oraz misji, którą jednostki samorządu terytorialnego realizują w społeczeństwie i wobec społeczeństwa.

Ponieważ kategorię niepomijalności administracji można rozpatrywać także w kontekście realizacji obowiązków prawnych organów administracji państwowej czy też rządowej, należy zaznaczyć, że wspólnym łącznikiem jest warunkowany art. 7 Konstytucji Rzeczypospolitej Polskiej obowiązek działania w granicach i na podstawie prawa. Niepomijalność administracji działającej w reżimach administracyjnych centralizacji oraz decentralizacji, nie oznacza kolizji kompetencji, gdyż w demokratycznym państwie prawnym ustawowa regulacja powinna zakładać koherencje działania organów w realizacji określonych ustawowo celów. Niemniej regulacja ustawodawstwa zwykłego nie powinna naruszać zasad ustrojowych, określających organizację struktur i działania organów administracji publicznej.

\section{Bibliografia}

Błaś A., Administracja publiczna w państwie prawa, [w:] Nauka administracji, red. J. Boć, Wrocław 2013.

Błaś A., Granice prywatyzacji zadań publicznych w państwie prawa, [w:] Samorząd terytorialny III Rzeczypospolitej Polskiej. 10 lat doświadczeń, red. S. Michałowski, Lublin 2002.

Chapus R., Droit administratif général, t. 1, Paris 2001.

Dytko J., Proceduralnoprawna determinacja nadzoru wojewody nad działalnościa prawotwórcza organów jednostek samorządu terytorialnego, Wrocław 2013.

Forges J.M. de, Droit administratif, Paris 1992.

Gaudemet Y., Traité de droit administratif, Paris 2001.

Giddens A., Living in. Post-traditional society, [w:] Reflexive Modernization: Politics, Tradition and Aesthetics in the Modern Social Order, red. U. Beck, S. Giddens, S. Lash, Stanford 1994.

Hałas E., Polityka symboliczna i pamięć zbiorowa. Zmiany nazwy ulic po komunizmie, [w:] Zmiana czy stagnacja?, red. M. Marody, Warszawa 2004.

Handel M., Fragmentaryzacja prawa administracyjnego w wyniku obowiazywania „specustaw”, „Internetowy Przegląd Prawniczy” 2018, nr 2.

https://ipn.gov.pl/pl/glowna/416,Inne-nazwy-wzbudzajace-kontrowersje.html.

https://ipn.gov.pl/pl/upamietnianie/dekomunizacja/zmiany-nazwulic/nazwy-ulic/nazwy-do-zmiany.

Kałużna J., Dekomunizacja przestrzeni publicznej w Polsce - zarys problematyki, „Środkowoeuropejskie Studia Polityczne” 2018, nr 2, DOI 10.14746/ssp.2018.2.10.

Kapralski S., Pamięć, przestrzeń, tożsamość. Próba refleksji teoretycznej, [w:] Pamięć, przestrzeń, tożsamość, red. S. Kapralski, Warszawa 2010.

Kasznica S. [A. Łużycki], Polskie prawo administracyjne: Pojęcia i instytucje zasadnicze, Warszawa 1938 [1943]. 
Koniuszewska E., Środki prawne ograniczające nadużycia władzy w jednostkach samorzadu terytorialnego w ustrojowym prawie administracyjnym, Warszawa 2009.

Lipowicz I., Samorząd terytorialny XXI wieku, Warszawa 2019.

Mejer A., Socjologia i przestrzeń miejska, Warszawa 2010.

Parchomiuk J., Wptyw koncepcji nadużycia prawa na administracyjnoprawny status jednostki, [w:] Jednostka wobec działań administracji publicznej, red. E. Ura, E. Feret, S. Pieprzny, Rzeszów 2016.

Rybicki Z., Piątek S., Zarys prawa administracyjnego i nauki administracji, Warszawa 1988.

Szreniawski P., Obowiazek w prawie administracyjnym, Lublin 2014.

Tabernacka M., Czynniki kształtujące tożsamość podmiotów sfery publicznej, [w:] Public Relations w sferze publicznej. Wizerunek i komunikacja, red. M. Tabernacka, A. Szadok-Bratuń, Warszawa 2013.

Tabernacka M., Płaszczyzna kulturowa konfliktów w administracji publicznej, [w:] Płaszczyzny konfliktów w administracji publicznej, red. M. Tabernacka, R. Raszewska-Skałecka, Warszawa 2010.

Tabernacka M., Płaszczyzna polityczna konfliktów w administracji publicznej, [w:] Płaszczyzny konfliktów w administracji publicznej, red. M. Tabernacka, R. Raszewska-Skałecka, Warszawa 2010.

Totalitaryzm, [hasło w:] Nowa encyklopedia powszechna PWN, Warszawa 2004.

Waline J., Droit administratif, Paris 2008.

\section{The matter of non-neglectability of public administration in the context of provisions that govern the naming and renaming of streets}

Summary

The article concerns the problem of the non-negligibility of public administration bodies, both local government and government administration in the context of the binding act on the ban on propagating communism. Significant factors affecting the non-negligibility of local government bodies is their systemic position in the state, which is related to the measures to protect the independence of their operation. The practice of exercising governmental supervisory powers under the Act on the prohibition of propagating communism, where one can notice a kind of automatism of these bodies, leads to the actual neglect of self-government bodies, which after all are bodies enjoying constitutionally guaranteed independence. This leads to conflicts in which the following factors play an important role: the question of assessing the historical significance of certain facts; the need to maintain the standard of independence of local government units as decentralized entities; the problem of the identity of local government units.

Keywords: public administration, non-negligence, totalitarianism, supervisory settlement, judicial protection of independence, decentralization. 